\title{
PERTUMBUHAN RIAP DIAMETER POHON BAKAU KURAP (Rhizophora mucronata) DI LAMPUNG MANGROVE CENTER
}

\section{DIAMETER INCREMENT GROWTH OF BAKAU KURAP (Rhizophora mucronata) IN LAMPUNG MANGROVE CENTER}

\author{
Robbi Angger Kesuma, Asihing Kustanti, dan Rudi Hilmanto \\ Jurusan Kehutanan, Fakultas Pertanian, Universitas Lampung \\ Jl. Soemantri Brojonegoro No 1 Bandar Lampung \\ Email : robbiangger@yahoo.co.id \\ Phone : 085783458289
}

\begin{abstract}
ABSTRAK
Bakau kurap ( $R$. mucronata) adalah tipe mangrove sejati, jenis ini dapat mencapai tinggi $27 \mathrm{~m}$ dan jarang melebihi $30 \mathrm{~m}$. Batang mangrove jenis ini memiliki diameter hingga $70 \mathrm{~cm} . R$. Mucronata ditemukan di Lampung Mangrove Center (LMC) Desa Margasari, Kecamatan Labuhan Maringgai, Kabupaten Lampung Timur. Penelitian ini bertujuan untuk mengetahui riap diameter, model pertumbuhan dan peramalan pertumbuhan tegakan $R$. mucronata di LMC. Penelitian ini dilaksanakan pada bulan Juli hingga Agustus 2015 dengan menggunakan metode pengukuran secara time series selama tiga tahun (2013, 2014, dan 2015) pada plot permanen berbentuk lingkaran dengan jari-jari sepanjang $7 \mathrm{~m}$ di LMC yang dibagi ke dalam tiga blok penjarangan ( $\mathrm{A}, \mathrm{B}$, dan $\mathrm{C}$ ). Blok $\mathrm{C}$ adalah blok kontrol atau blok yang tidak dijarangi dan besar penjarangan pada Blok A dan Blok B secara berturut 54,5\% dan 41,7\%. Hasil penelitian ini menunjukan bahwa riap diameter terbesar dari ketiga Blok pada umur 22 tahun $=0,467 \mathrm{~cm}_{\text {tahun }^{-1}}$. Model penduga diameter (D) dan riap diameter (MAI-d) berdasarkan umur tegakan (X) dapat dinotasikan sebagai berikut: 1) Blok A D = 8,996 $\mathrm{X}^{0,021}$; MAI-d $=0,451 \mathrm{X}^{0,035}, 2$ ) Blok B D $=8,215 \mathrm{X}^{0,124}$; MAI-d $=0,412 \mathrm{X}^{0,039}$, 3) Blok C D = 7,159 $\mathrm{X}^{0,074}$; MAI-d $=0,359 \mathrm{X}^{(-0,012)}$. Peramalan pertumbuhan diameter tegakan $R$. mucronata umur 32 tahun pada blok A, B dan C secara berturut-turut adalah $10,280 \mathrm{~cm}, 9,463 \mathrm{~cm}$, dan $7,796 \mathrm{~cm}$ sedangkan riap diameternya adalah $0,467 \mathrm{~cm}, 0,430 \mathrm{~cm}$, dan $0,354 \mathrm{~cm}$.
\end{abstract}

Kata kunci : Lampung Mangrove Center, peramalan, Rhizophora mucronata, riap diameter

\section{ABSTRACT}

Bakau kurap (R. mucronata) is a true mangrove. The height of this mangrove could reach 27 $m$ and rarely exceed $30 \mathrm{~m}$. The diameter trunk of this mangrove could reach $70 \mathrm{~cm} . R$. mucronata stands was found in Lampung Mangrove Center (LMC), it was located in Margasari Village district Labuhan Maringgai, East Lampung Regency. The purposes of this study were to determine the diameter increment, growth models and stand growth past of $R$. mucronata at LMC. The research was conducted on July to August 2015. The method used measurement of diameter time series for three years (2013, 2014, and 2015) on circle form permanent plots with a radius $7 \mathrm{~m}$ of length are divided into three thinning blocks $(A, B$, and $C)$. Block $C$ was the control block or block that was not thinned and large thinning in blocks $A$ and $B$, respectively $54.5 \%$ and $41.7 \%$. The results indicated that the biggest diameter increment of three block at the age of $22^{\text {nd }}$ years $=0.467 \mathrm{~cm}$ year ${ }^{-1}$. The estimation model of stand diameter $(D)$ and diameter increment $(M A I-d)$ based on the age of stand $(X)$ could be formulated as follows: 1) Blok $A D=8,996 X^{0,021}$; MAI-d $=0,451 X^{0,035}$, 2) Blok B D =8,215 $X^{0,124} ;$ MAI-d $=0,412 X^{0,039}$, 3) Blok $C D=7,159 X^{0,074} ;$ MAI-d $=0,359 X^{(-0,012)}$. Forecasting growth stands diameter $R$. mucronata age of $32^{\text {nd }}$ years on the blocks $A, B$ and $C$ in a row 
were $10,280 \mathrm{~cm}, 9,463 \mathrm{~cm}$, and $7,796 \mathrm{~cm}$ while the diameter increment were $0,467 \mathrm{~cm}, 0,430 \mathrm{~cm}$, and $0,354 \mathrm{~cm}$.

Key words : Diameter increment, forecasting, Lampung Mangrove Center, Rhizophora mucronata

\title{
PENDAHULUAN
}

Hutan mangrove merupakan ekosistem hutan unik dan kompleks. Tipe vegetasi hutan ini didominasi oleh tanaman berkayu yang digenangi oleh air laut atau dipengaruhi oleh pasang surut air laut, daerah pantai dengan kondisi tanah berlumpur, berpasir atau lumpur berpasir (Onrizal, 2008).

Rhizophora mucronata adalah tipe mangrove sejati. Jenis tersebut dapat mencapai tinggi $27 \mathrm{~m}$, dan jarang melebihi $30 \mathrm{~m}$. Batang memiliki diameter hingga $70 \mathrm{~cm}$ dengan kulit kayu berwarna gelap hingga hitam. Penyebaran $R$. mucronata adalah Afrika Timur, Madagaskar, Mauritania, Asia tenggara, seluruh Malaysia dan Indonesia, Melanesia dan Mikronesia. Ekologi tempat tumbuh $R$. mucronata di areal yang sama dengan Rhizophora apiculata tetapi lebih toleran terhadap substrat yang lebih keras dan pasir (Noor, dkk., 2006). Salah satu kawasan hutan yang menjadi ekosistem mangrove jenis $R$. mucronata adalah Lampung Mangrove Center (LMC). LMC terletak di Desa Margasari yang berada di Kecamatan Labuhan Maringgai, Kabupaten Lampung Timur. Menurut Kustanti (2014) luasan mangrove di LMC seluas $700 \mathrm{Ha}$.

Penelitian ini penting dilakukan karena pertumbuhan merupakan tulang punggung ilmu pengelolaan hutan, yang bertujuan untuk mengetahui potensi tegakan (Mulia, 1995), selain itu riap diameter yang didapatkan dari hasil penelitian ini akan berguna untuk mengetahui waktu yang tepat dalam memanen hasil hutan dari $R$. mucronata secara optimal tanpa merusak ekosistem dan tegakannya. Penelitian ini merupakan kelanjutan dari penelitian sebelumnya yang telah dilakukan oleh peneliti dari Hokkaido University Japan dan Universitas Lampung terhadap R. mucronata pada tahun 2013 dan 2014 yang menerapkan sistem silvikultur pada plot permanen di LMC.

\section{METODE PENELITIAN}

\section{Waktu dan Lokasi Penelitian}

Penelitian ini dilaksanakan pada bulan Juli hingga Agustus 2015. Lokasi penelitian berada di Lampung Mangrove Center (LMC), Desa Margasari, Kecamatan Labuhan Maringgai, Kabupaten Lampung Timur.

\begin{abstract}
Alat dan Bahan
Objek yang menjadi bahan penelitian adalah hutan mangrove tegakan bakau kurap $(R$. mucronata) di LMC, data sekunder diameter batang $R$. Mucronata pada tahun 2013 dan 2014, dan 3 blok penjarangan yaitu Blok A, Blok B dan Blok C yang masing-masing blok terdapat 3 plot permanen berbentuk lingkaran dengan jari-jari sepanjang 7m, pada tahun 2013 telah dilakukan penjarangan dan ditetapkan bahwa Blok $\mathrm{C}$ adalah blok kontrol atau blok yang tidak dijarangi dan Blok A dan Blok B adalah blok penjarangan dengan besar penjarangan secara berturut $54,5 \%$ dan $41,7 \%$.. Alat yang digunakan dalam penelitian ini meliputi, computer, Software statistik, tally sheet, alat tulis, kamera, dan pita meter.
\end{abstract}




\section{Metode Penelitian}

Objek penelitian ini adalah tegakan mangrove jenis $R$. Mucronata. Metode yang digunakan dalam penelitian ini adalah data time series dengan mengukur diameter pohon pada plot permanen dari tahun ke tahun yang telah dilakukan selama 2 tahun (2013 dan 2014) dan yang akan dilakukan pada tahun 2015, pohon yang diukur hanya pohon yang telah di berikan nomor dan ditandai oleh pita merah serta cat merah, pada saat penjarangan pada tahun 2013 guna mengetahui laju pertumbuhan pada pohon yang sama pada tahun tahun berikutnya. Pengukuran diameter merupakan langkah awal yang dilakukan untuk mengetahui riap diemeter yang meliputi riap diameter individu, riap diameter rata-rata tahunan (MAI), dan riap diameter rata-rata berjalan (CAI) dengan cara analisis data, langkah selanjutnya yang dilakukan adalah analisis statistik untuk membuat suatu model prediksi terhadap riap diameter.

\section{Analisis Data}

Analisis data diperlukan untuk menjadi dasar dilakukannya sintesis data yang berguna untuk menjawab tujuan penelitian. Parameter kuantitatif dalam pengukuran riap diameter adalah sebagai berikut :

- Diameter pohon diperoleh dari konversi keliling sebagai berikut:

(Dephut, 1992 dalam Abdurachman, 2012)

$\mathrm{D}=\mathrm{K} / \pi$

$\mathrm{D}=$ diameter pohon $(\mathrm{cm})$

$\mathrm{K} \quad=$ keliling pohon $(\mathrm{cm})$

$\pi \quad=($ konstanta phi $)=3,1415$

- Riap diameter pohon diperoleh dari rumus berikut:

(Susila, 2010)

$\mathrm{Rd}=\left(\mathrm{d}_{2}-\mathrm{d}_{1}\right) / \mathrm{nu}$

$\mathrm{Rd}=$ riap diameter pohon $(\mathrm{cm} / \mathrm{th})$

$\mathrm{d}_{2} \quad=$ diameter tahun ke dua

$\mathrm{d}_{1} \quad=$ diameter tahun ke satu

nu $=$ selang waktu antar pengukuran

- Riap rata-rata tahunan/mean annual increment (MAI)

(Susila, 2010)

$\mathrm{MAI}=\mathrm{D}_{\mathrm{t}} / \mathrm{t}$

$\mathrm{D}_{\mathrm{t}} \quad=$ diameter pohon pada umur ke-t $(\mathrm{cm})$

$\mathrm{t} \quad=$ umur (tahun)

- Riap rata-rata berjalan/current annual increment (CAI)

(Susila, 2010)

$\mathrm{CAI}=\left(\mathrm{D}_{\mathrm{t}}-\mathrm{D}_{\mathrm{t}-1}\right) / \mathrm{T}$

$\mathrm{D}_{\mathrm{t}} \quad=$ diameter pohon pada umur ke-t $(\mathrm{cm})$

$\mathrm{D}_{\mathrm{t}-1}=$ diameter pohon tahun sebelumnya $(\mathrm{cm})$

$\mathrm{T} \quad=$ jarak waktu pengukuran (bulan)

Penentuan model pendugaan riap diameter analisis data menggunakan lima model regresi, lima model regresi dipilih karena model tersebut umum digunakan dalam melakukan peramalan terutama pada dua variabel, pertimbangan lainnya karena lima bentuk tersebut adalah bentuk yang sederhana yang dapat mewakili peramalan dan pembuatan model regresi 
pada riap. Lima model persamaan regresi yang dicobakan dari indikasi parameter-parameter tersebut yaitu (Susila, 2010) :

- Regresi Linear $\quad: Y=a+b X$

- Regresi Logaritma : $Y=a+b \log X$

- Regresi Kuadratik : $Y=a+b X+c X^{2}$

- Regresi Eksponen $: \mathrm{Y}=\mathrm{a}+\mathrm{b}^{\mathrm{X}}$

- Regresi power $\quad: \mathrm{Y}=\mathrm{a} \mathrm{X}^{\mathrm{b}}$

Dimana Y adalah dugaan parameter tertentu (cm atau m); X adalah umur tegakan; a dan $\mathrm{b}$ adalah konstanta.

\section{HASIL DAN PEMBAHASAN}

\section{Hasil Penelitian}

Pengukuran pertumbuhan diameter pada tegakan bakau kurap ( $R$. mucronata) pada plot permanen hutan pendidikan Lampung Mangrove Center yang dilakukan pada tahun 2013, 2014, dan 2015. Pertumbuhan $R$. mucronata pada 3 blok penjarangan yaitu Blok A, Blok B dan Blok $\mathrm{C}$ yang dibagi berdasarkan persentase penjarangan. Data penjarangan disajikan pada Tabel 1.

Tabel 1. Blok Penjarangan.

\begin{tabular}{cccccc}
\hline \multirow{2}{*}{ Blok } & \multirow{2}{*}{ Jumlah Pohon $\left(\mathrm{ha}^{-1}\right)$} & \multirow{2}{*}{ Penjarangan $(\%)$} & \multicolumn{3}{c}{ Diameter rata-rata tahun $(\mathrm{cm})$} \\
\cline { 4 - 6 } A & 2,555 & 54,5 & 2013 & 2014 & 2015 \\
B & 3,053 & 41,7 & 9,001 & 9,767 & 10,280 \\
C & 5,500 & 0 & 7,238 & 8,889 & 9,463 \\
\hline
\end{tabular}

Sumber: Okimoto (2013), Data Primer Okimoto (2014)

\section{Riap Diameter}

Data yang didapatkan meliputi diameter tegakan selama 3 tahun (2013, 2014 dan 2015), setelah dilakukannya analisis data diperoleh hasil riap tahunan rata-rata (MAI) dan riap ratarata berjalannya (CAI) yang disajikan pada Tabel 2 dan dijelaskan dalam bentuk grafik pada Gambar 1.

Tabel 2. Riap diameter tegakan R. mucronata di LMC Tahun 2013, 2014, dan 2015.

\begin{tabular}{lcccc}
\hline \multirow{2}{*}{ Rata-rata Tahunan } & \multicolumn{3}{c}{ Plot Permanen } & \multirow{2}{*}{ Rata-rata $(\mathrm{cm})$} \\
\cline { 2 - 4 } & Blok A $(\mathrm{cm})$ & Blok B $(\mathrm{cm})$ & Blok C $(\mathrm{cm})$ & \\
\hline MAI Tahun 2013 & 0,450 & 0,412 & 0,359 & 0,407 \\
MAI Tahun 2014 & 0,465 & 0,423 & 0,357 & 0,415 \\
MAI Tahun 2015 & 0,467 & 0,430 & 0,354 & 0,417 \\
CAI Tahun 2014 & 0,070 & 0,059 & 0,029 & 0,053 \\
CAI Tahun 2015 & 0,043 & 0,048 & 0,025 & 0,039 \\
Diameter Tahun 2013 & 9,001 & 8,238 & 7,174 & 8,138 \\
Diameter Tahun 2014 & 9,767 & 8,889 & 7,494 & 8,717 \\
Diameter Tahun 2015 & 10,280 & 9,463 & 7,796 & 9,180 \\
\hline
\end{tabular}

Sumber: Okimoto dkk (2013), Data Primer Okimoto (2014) 


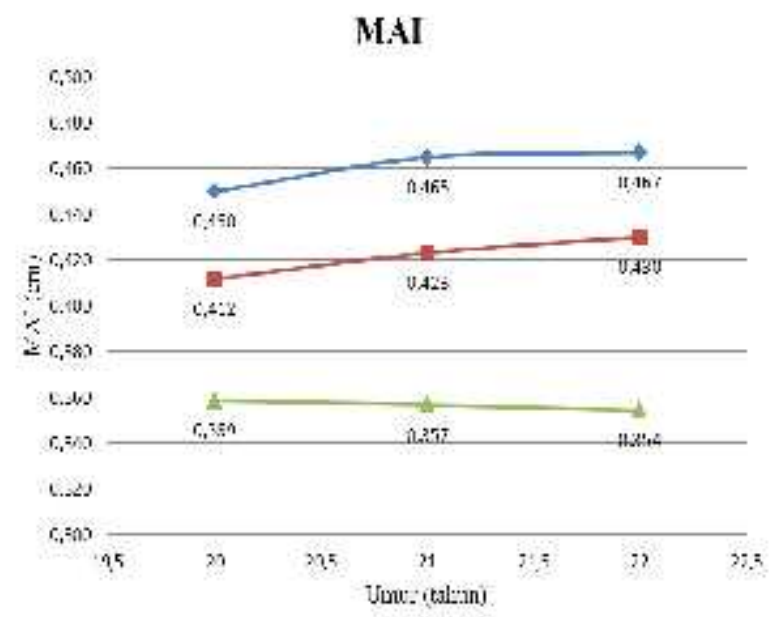

(a)

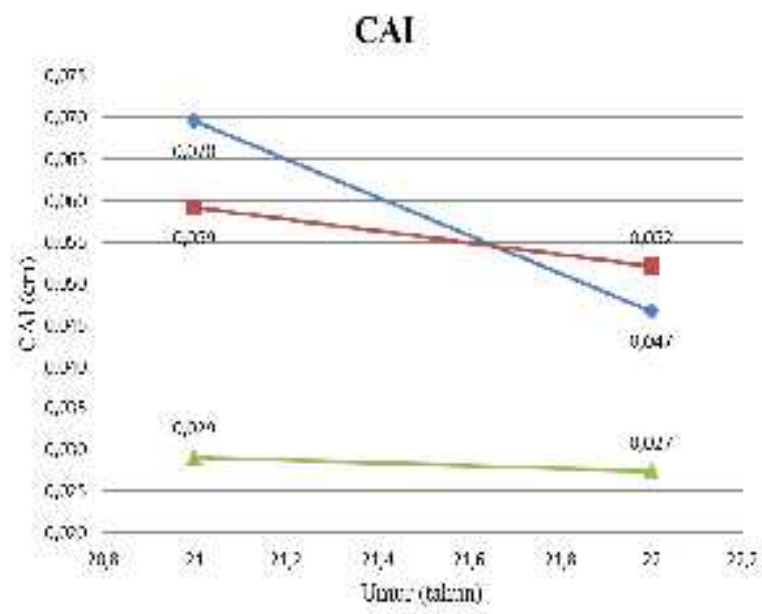

(b)

Diameter

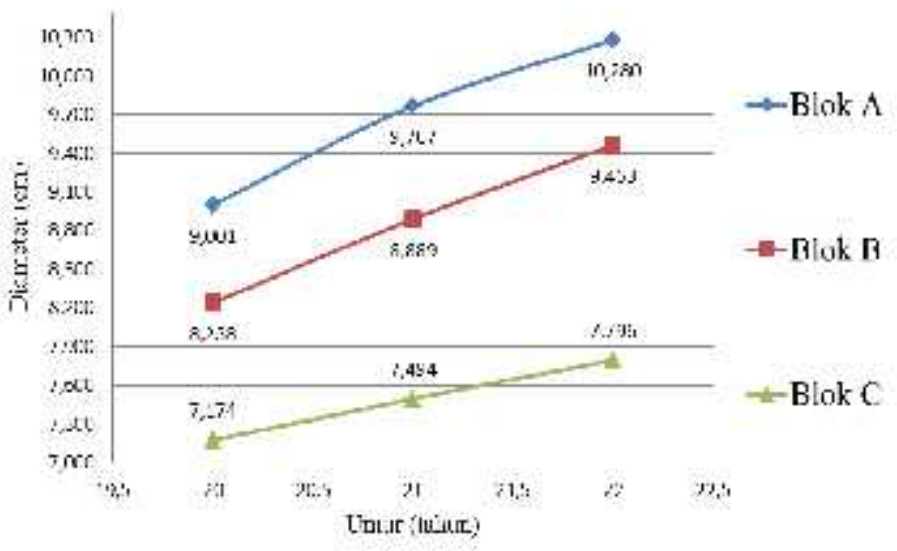

(c)

Gambar 1. (a) Pertumbuhan Riap Tahunan Rata-Rata (MAI) Diameter, (b) Pertumbuhan Riap Rata-Rata Berjalan (CAI) Diameter dan (c) Pertumbuhan Diameter Tahun 2013, 2014, dan 2015 pada $R$. mucronata.

\section{Prediksi dan Pemodelan}

Penjelasan tentang model model regresi riap diameter dan diameter dari ketiga blok disajikan dalam bentuk grafik pada Gambar 2 yang dilengkapi dengan trendline masingmasing model regresi untuk mempermudah dalam pemilihan bentuk model regresi.

Tabel 3. menyajikan data tentang model yang terpilih untuk diameter dan riap tahunan rata-rata (MAI). Model yang telah terpilih diperkenankan untuk menjadi model prediksi pertumbuhan berdasarkan pertimbangan mengenai koefisien determinasi $\left(\mathrm{R}^{2}\right)$, dan Galat baku/standard error (SE). 


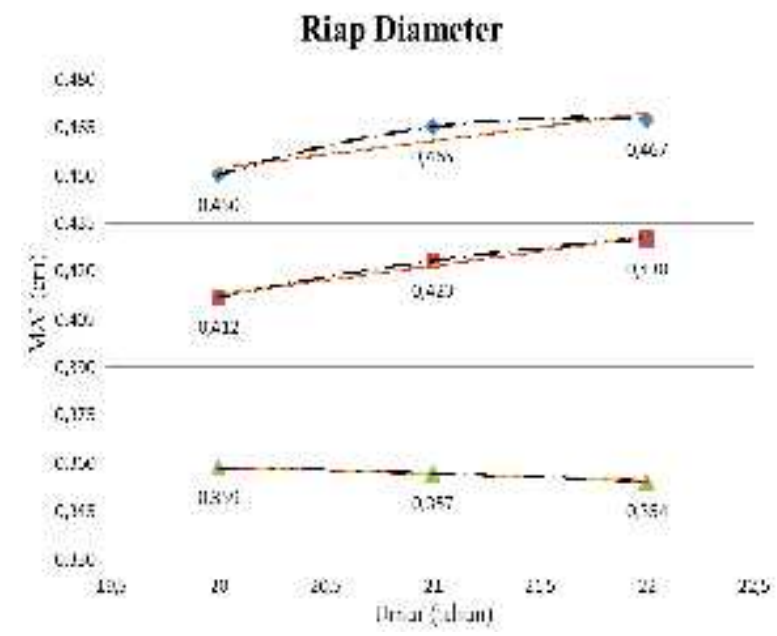

(a)

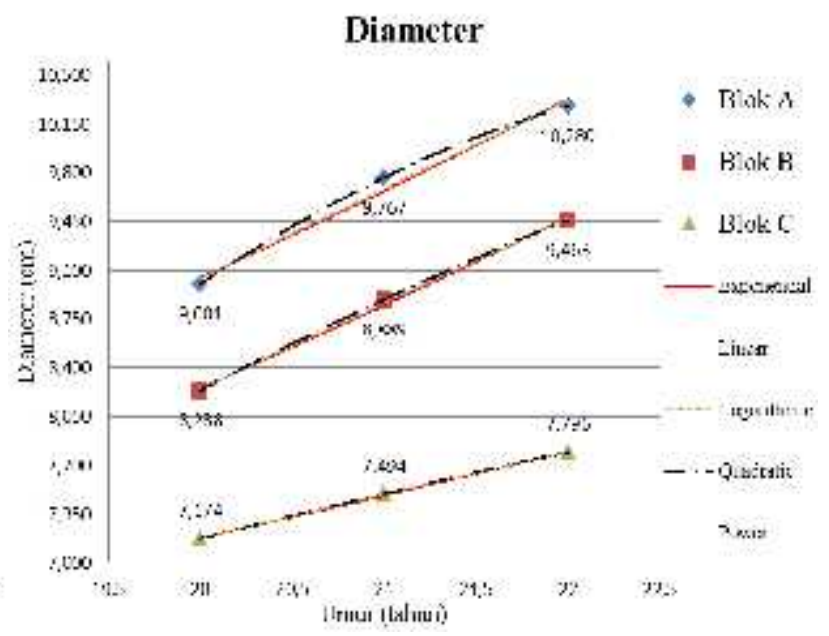

(b)

Gambar 2. (a) Trendline Model Regresi Riap Diameter dan (b) Trendline Model Regresi Diameter untuk $R$. mucronata.

Tabel 3. Model-model Regresi Terpilih Tegakan Bakau Kurap (R. Mucronata) di Lampung Mangrove Center.

\begin{tabular}{clcc}
\hline NO & \multicolumn{1}{c}{ Model Regresi } & $\mathrm{R}^{2}(\%)$ & $\mathrm{Se}$ \\
\hline 1 & MAI-d Blok A $=0,451 \mathrm{X}^{0,035}$ & 93,00 & 0,008 \\
2 & MAI-d Blok B = 0,412 X & 100,00 & 0,001 \\
3 & MAI-d Blok C $=0,359 \mathrm{X}^{(-0,012)}$ & 93,10 & 0,003 \\
4 & Diameter Blok A = 8,996 X,021 & 100,00 & 0,002 \\
5 & Diameter Blok B $=8,215 \mathrm{X}^{0,124}$ & 99,10 & 0,009 \\
6 & Diameter Blok C $=7,159 \mathrm{X}^{0,074}$ & 98,50 & 0,007 \\
\hline
\end{tabular}

Keterangan: $\mathrm{X}=$ Umur Tegakan

Prediksi Riap Tahunan Rata-rata (MLI)

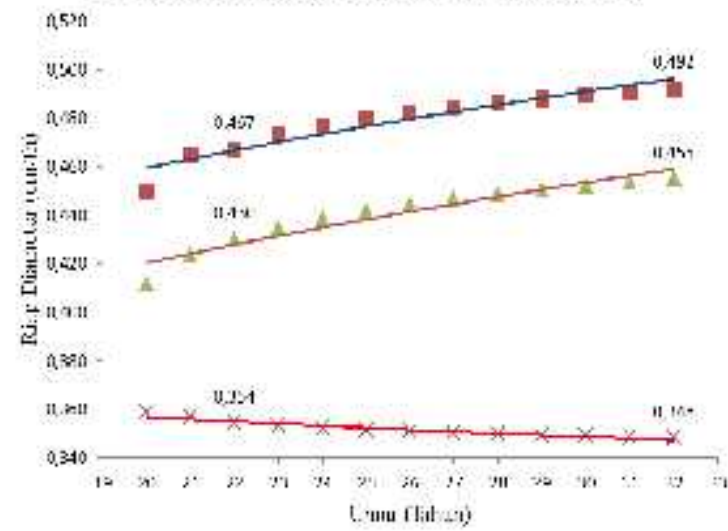

(a)

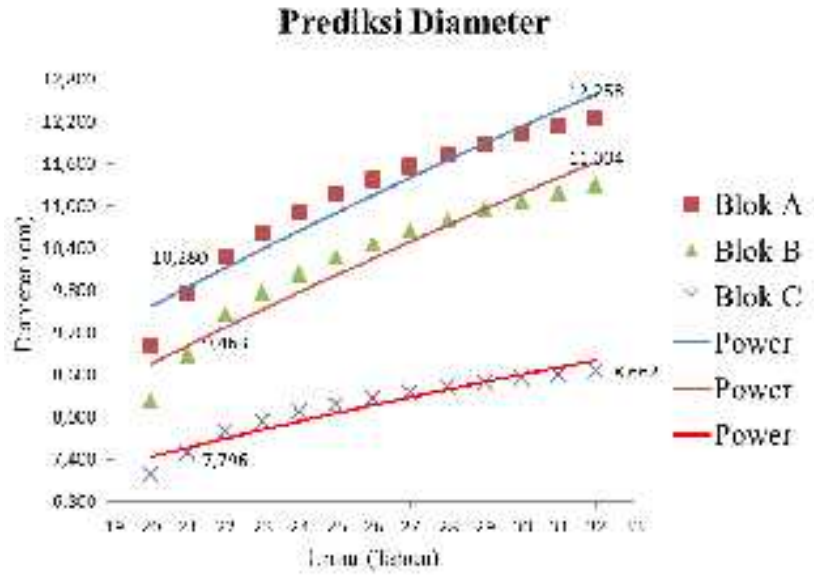

(b)

Gambar 3. (a) Grafik Prediksi Riap Tahunan Rata-rata (MAI) dan (b) Grafik Prediksi Diameter untuk $R$. mucronata.

Prediksi terhadap riap diameter didapatkan dari model yang telah telah terpilih berdasarkan hasil uji analisis regresi yang selanjutnya akan dilakukannya perhitungan untuk 
mengetahui peramalan terhadap pertumbuhan riap diameternya dengan memasukan variabelvariabel yang terkait. Data tentang prediksi riap diameter $R$. mucronata dijelaskan dalam Grafik dengan trendline model regresi terpilih yang menjelaskan tentang prediksi riap diameter sepuluh tahun kedepan dimulai dari umur 23 tahun sampai dengan umur 32 tahun.pada Gambar 3.

\section{Pembahasan}

\section{Riap Diameter}

Hasil pengukuran diameter tegakan $R$. mucronata selama tiga tahun disajikan dalam tabel 2 dan dijelaskan pada gambar 1 dalam bentuk grafik yang menunjukan peningkatan atau penurunan nilai. Diameter rata-rata pada tahun 2015 atau pada umur 22 mengalami peningkatan dari tahun sebelumnya, pada tahun 2015 diameter tegakan blok A, blok B dan blok C secara berturut turut adalah 10,280, 9,463, dan 7,796. Pertumbuhan diameter secara keseluruhan setiap blok mengalami kenaikan, namun terjadi fluktuasi pada pertumbuhan riapnya antara riap tahunan rata-rata (MAI) dan penurunan pada riap rata-rata berjalan (CAI). MAI diameter pada blok A dan blok B mengalami kenaikan setiap tahunnya, pada tahun 2015 MAI yang diperoleh pada blok A dan Blok B secara berturut adalah 0,467 dan 0,430. Gambar 1 menunjukan bahwa kenaikan terjadi pada dua blok yaitu blok A dan blok B, namun pada blok $C$ terjadi penurunan sebesar 0,003 dari tahun 2014 ke tahun 2015. Pertumbuhan MAI pada blok $\mathrm{C}$ mengalami penurunan namun diameter pertahun pada blok $\mathrm{C}$ tetap mengalami kenaikan, hal tersebut menjelaskan bahwa pertumbuhan diameter pertahun pada blok $\mathrm{C}$ sangat kecil bila dibandingkan dengan dua blok lainnya. CAI pada ketiga blok pengamatan mengalami penurunan dari tahun 2014 ke tahun 2015, hal ini menunjukan bahwa pertumbuhan diameter perbulan dari tahun 2014 ke tahun 2015 sangat kecil bila dibandingkan dengan pertumbuhan dari tahun 2013 ke tahun 2014.

CAI adalah riap rata-rata yang dilihat berdasarkan pertumbuhan perbulannya sedangkan MAI adalah riap yang dilihat berdasarkan pertumbuhan pertahunnya, pengertian tersebut dapat ditarik kesimpulan bahwa selain dari faktor substrat yang mempengaruhi pertumbuhan, ada pula faktor bulanan dan faktor tahunan yang mempengaruhi pertumbuhan, faktor tersebut adalah iklim, hal ini diperkuat oleh pernyataan Latifah (2004) yang menyatakan bahwa iklim berpengaruh dalam pertumbuhan tanaman. Alrasyid dalam Susila (2010) menambahkan bahwa faktor iklim yang sangat berperan dalam pertumbuhan adalah jumlah musim (hujankemarau), iklim mempengaruhi perkembangan tumbuhan dan perubahan faktor fisik (substrat dan air). Alwidakdo (2014) menjelaskan iklim juga mempengaruhi pertumbuhan mangrove melalui cahaya, curah hujan, suhu dan angin.

Pertumbuhan diameter dan pertumbuhan riap diameternya dipengaruhi oleh faktorfaktor yang mempengaruhi pertumbuhan diantaranya adalah substrat, substrat yang dimaksud disini adalah substrat yang mengandung lumpur lunak. $R$. mucronata dapat hidup pada tempat yang kurang mengandung lumpur, karena pertumbuhan mangrove terpengaruh oleh kandugan oksigen terlarut didalam lumpur dan ketebalan lumpur yang optimal untuk pertumbuhan $R$. mucronata adalah $30 \mathrm{~cm}$ (Halidah, 2010). Budiman dkk (2015) menambahkan bahwa pertumbuhan diameter pohon dipengaruhi oleh faktor lingkungan, dimana faktor lingkungan dipengaruhi oleh potensi tanah bagi pertumbuhan tanaman. Potensi tanah dilihat dari dua aspek yaitu kondisi fisik tanah dan aspek kimia tanah.

Pertumbuhan paling besar terdapat pada Blok A yang dengan presentase penjarangan paling besar dibandingkan dengan kedua blok lainnya baik itu diameter, MAI maupun CAI. Menurut Lal (1960) dalam Latifah (2004) faktor-faktor yang mempengaruhi besar kecilnya riap suatu tegakan adalah tindakan silvikultur, tindakan silvikultur yang dimaksudkan disini adalah penjarangan tegakan. Penjarangan menyebabkan berkurangnya kompetisi antar 
individu pohon dalam pemanfaatan ruang tumbuh, baik terhadap pemanfaatan sinar matahari maupun terhadap unsur hara di dalam tanah sehingga pertumbuhan tegakan relatif lebih cepat daripada sebelumnya (Susila, 2010). Tindakan silvikultur yang diberikan dapat mengurangi persaingan antar pohon yang terjadi dalam suatu tegakan sehingga pohon-pohon yang tetap hidup dapat memperoleh ruang tumbuh yang lebih baik (Krisnawati dan Wahjono, 2004 dalam Ayuningtyas, 2015).

Penjarangan mempengaruhi besarnya intensitas cahaya dan ketersediaan unsur hara yang dibutuhkan bagi tanaman. Semakin lebar jarak tanam, semakin besar intensitas cahaya dan semakin banyak ketersediaan unsur hara bagi individu tanaman, karena jumlah pohonnya lebih sedikit. Sebaliknya semakin rapat jarak tanam semakin banyak jumlah pohonnya dan persaingan semakin ketat (Mawazin dan Suhaendi, 2008) hal tersebut diperkuat oleh pernyataan Okimoto dkk (2013) yang menyebutkan bahwa penjarangan yang dilakukan pada tegakan $R$. mucronata di plot permanen LMC menyebabkan intensitas cahaya matahari yang masuk lebih besar mencapai 15,6-18,6 \% dibandingkan dengan sebelumnya yang hanya 2,24\%. Prastyono (2014) menyebutkan bahwa pertumbuhan pohon dipengaruhi oleh intensitas cahaya, karena intensitas cahaya mempengaruhi proses fotosintesis, Thojib (1988) dalam Yunianti (2009) menambahkan bahwa pertumbuhan merupakan hasil dari interaksi berbagai proses fisiologis, proses fisiologis yang dimaksud adalah fotosintesis, respirasi dan transpirasi.

\section{Prediksi dan Pemodelan}

Setelah dilakukan perhitungan terhadap hasil pengukuran diameter tegakan $R$. mucronata selama tiga tahun pada bentang umur 20 tahun sampai 22 tahun selanjutnya dilakukan uji analisis statistik untuk menentukan model regresi yang tepat untuk menggambarkan atau memprediksi pertumbuhan diameter maupun riapnya pada tahun-tahun kedepannya.

Penyusunan model berdasarkan persamaan regresi yang menggunakan satu peubah diperkenankan galat baku 25\%, sedangkan apabila menggunakan dua peubah diperkenankan galat baku 20\% (Prodan, 1965 dalam Bustomi, 2006). Keselerasan model regresi dapat diterangkan dengan menggunakan nilai $\mathrm{R}^{2}$, jika nilai mendekati 1 maka model regresi semakin baik. Nilai $\mathrm{R}^{2}$ mempunyai karakteristik diantaranya: selalu positif, nilai $\mathrm{R}^{2}$ maksimal sebesar 1. Jika Nilai $\mathrm{R}^{2}$ sebesar 1 akan mempunyai arti kesesuaian yang sempurna. Maksudnya seluruh variasi dalam variabel terikat (variabel $\mathrm{Y}$ ) dapat diterangkan oleh model regresi. Sebaliknya jika $\mathrm{R}^{2}$ sama dengan 0 , maka tidak ada hubungan linier antara variabel bebas (variabel X) dan variabel terikat (variabel Y) (Sarwono, 2013).

Tabel 3 menunjukan bahwa galat baku yang didapatkan untuk model (MAI) rata-rata tiga blok yang terpilih sebesar $0,3 \%$ sedangkan pada blok A, blok B, dan blok C secara berturut-turut adalah $0,8 \%, 0,1 \%$, dan 0,1 hal ini sesuai dengan galat baku yang diperkenankan yaitu kurang dari $25 \%$. Koefisien determinasi dari model yang telah terpilih untuk riap tahunan rata-rata (MAI) cukup tinggi (>95\%) mencapai 96,7\% dan pada blok A, blok B dan blok C adalah 93\%, 100\%, dan 93,1\% hal tersebut menunjukan bahwa keterikatan hubungan antara variabel bebas (umur) dan variabel terikat (MAI) model tersebut diperkenankan karena galat baku atau standard error kurang dari 25\%, sedangkan hubungan keterikatan antara variable bebas (umur) dan variabel terikat (MAI) cukup relevan karena mencapai $>95 \%$. Galat baku untuk rata-rata diameter dari tiga blok adalah $0,6 \%$ sedangkan blok A, blok B dan blok $\mathrm{C}$ secara berturut-turut adalah 0,2\%, 0,9\% dan 0,7\%, koefisien determinasi yang didapatkan untuk diameter rata-rata tiga blok mencapai 99,5\% sedangkan blok A, blok B, dan blok C secara berturut-turut mencapai 100\%, 99,1\% dan 100\% hal tersebut menunjukan bahwa keterikatan hubungan antara variabel bebas (umur) dan variabel terikat (diameter) model tersebut diperkenankan karena galat baku yang didapatkan kurang 
dari $25 \%$ dan galat baku yang didapatkan mencapai lebih dari 95\%. Dari penjelasan kedua model tersebut menunjukan bahwa kedua model tersebut cukup relevan untuk dijadikan acuan dalam melakukan peramalan (forecasting).

Data tentang MAI dan diameter pada umur 20 tahun sampai 22 tahun disajikan dalam bentuk grafik pada gambar 3 berdasarkan pengukuran yang telah dilakukan selama tiga tahun serta prediksi pada umur 23 tahun sampai umur 32 tahun berdasarkan model terpilih. Prediksi pertumbuhan diameter paling besar terdapat pada blok A yang mencapai 12,258 pada umur 32 tahun, hasil tersebut lebih kecil di bandingkan dengan pernyataan Choesin (2011) yang menyebutkan bahwa pertumbuhan diameter Rhizopora sp mencapai 12,39 $\mathrm{cm}$ pada umur 29 tahun. Pertumbuhan diameter mangrove lebih kecil dibandingkan dengan tanaman slow growing lainnya, contohnya dengan pertumbuhan diameter Jati (Tectona grandis) yang menurut Kementrian Kehutanan (2013) pada umur 20 tahun diameter Jati mencapai $22 \mathrm{~cm}$.

\section{SIMPULAN}

Simpulan dati penilitian ini adalah sebagai berikut :

1. Berdasarkan pengukuran selama tiga tahun dari tahun 2013, 2014 dan 2015 didapatkan data diameter rata-rata tegakan Rhizopora mucronata di Lampung Mangrove Center masing-masing blok secara berturut-turut untuk blok A dengan besar penjarangan $54,4 \%$ adalah 9,$001 ; 9,767 ; 10,280$ untuk blok B dengan besar penjarangan $47,1 \%$ adalah 8,238 ; 8,889; 9,463; dan untuk blok C sbagai blok kontrol adalah 7,174; 7,494; 7,796.

2. Riap rata-rata berjalan (CAI) tahun 2014 dan 2015 masing-masing blok secara berturutturut untuk blok A 0,070; 0,043 untuk blok B 0,059; 0,048 dan untuk blok C mencapai 0,029; 0,025 sedangkan Riap rata-rata tahunan (MAI) tahun 2013, 2014 dan 2015 masingmasing blok secara berturut-turut untuk blok A 0,$450 ; 0,465 ; 0,467$ untuk blok B 0,412 ; 0,$423 ; 0,430$ dan untuk blok C 0,359; 0,357; 0,354.

3. Pemodelan yang dipilih berdasarkan uji analisis regresi untuk pendugaan diameter dengan umur sebagai variabel bebas $(\mathrm{X})$ dan diameter sebagai variabel terikat (Y) untuk blok $\mathrm{A}$ adalah $\mathrm{Y}=8,996 \mathrm{X}^{0,021}$ dengan galat baku $0,2 \%$ dan koefisien determinasi sebesar $100 \%$, untuk blok B adalah $\mathrm{Y}=8,215 \mathrm{X}^{0,124}$ dengan galat baku $0,9 \%$ dan koefiesien determinasi mencapai 99,1\% sedangkan untuk blok $\mathrm{C}$ adalah $\mathrm{Y}=6,866+0,311 \mathrm{X}$ dengan galat baku sebesar $0,7 \%$ dan koefisien determinasinya mencapai $100 \%$.

\section{DAFTAR PUSTAKA}

Abdurachman. 2012. Riap diameter hutan bekas tebangan setelah 20 tahun perlakuan perbaikan tegakan tinggal di Labanan Berau. Jurnal Penelitian Dipterokarpa. 6(2):121-129.

Alwidakdo, A., Azham, Z. dan Kamarubayana, L. 2014. Studi pertumbuhan mangrove pada kegiatan rehabilitasi hutan mangrove di Desa Tanjung Limau Kecamatan Muara Badak Kabupaten Kutai Kartanegara. Jurnal AGRIFOR. 13(1):11-18.

Ayuningtyas, A. 2015. Riap diameter dan volume tegakan hutan alam di areal iuphhk-ha pt gunung gajah abadi kalimantan timur. Skripsi. Institut Pertanian Bogor. Bogor. 41 hlm.

Budiman, M., Hardiansyah, G., dan Darwati, H. 2015. Estimasi biomassa karbon serasah dan tanah pada basal area tegakan Meranti Merah (Shorea macrophylla) di areal arboretum Universitas Tanjungpura Pontianak. Jurnal Hutan Lestari. 3(1):98-107.

Bustomi, S., 2006. Pendugaan isi pohon jenis puspa di daerah Sukabumi ,Jawa Barat. Jurnal Penelitian Hutan Tanaman. 3(1):209-222. 
Choesin, D.N. 2011. Pengaruh umur tanam terhadap penguraian dan produksi jatuhan serasah (studi kasus ekosistem mangrove Rhizophora sp.). Skripsi. Institut Teknologi Bandung. Bandung. 78 hlm.

Halidah, 2010. Pertumbuhan Rhizophora mucronata lamk pada berbagai kondisi substrat di kawasan rehabilitasi mangrove Sinjai Timur Sulawesi Selatan. Jurnal Penelitian Hutan dan Konservasi Alam. 7(4):399-412.

Kementrian Kehutanan. 2013. Manual Budidaya Jati. Buku. Badan Penelitian dan Pengembangan Kehutanan. Bogor. $18 \mathrm{hlm}$.

Kustanti, A., Nugroho, B., Nurrochmat, D.R. dan Okimoto, Y. 2014. Evolusi hak kepemilikan dalam pengelolaan ekosistem hutan mangrove di Lampung Mangrove Center. Jurnal Risalah Kebijakan Pertanian dan Lingkungan. 1(3):143-158.

Latifah, S. 2004. Pertumbuhan Dan Hasil Tegakan Eucalyptus grandis Di Hutan Tanaman Industri. Universitas Sumatra Utara. Sumatra Utara. https://www.google.co.id/webhp?sourceid=chromeinstant\&ion=1\&espv=2\&ie=UTF8 \#q=Latifah\%2C+S.+2004.+Pertumbuhan+Dan+Hasil+Tegakan+Eucalyptus+grandis+ Di+Hutan+Tanaman+Industri. Diakses pada 11 April 2015 pukul 14.24 WIB.

Mawazin dan Suhaendi, H. 2008. Pengaruh jarak tanam terhadap pertumbuhan diameter Shorea parvifolia Dyer. Jurnal Penelitian dan Konservasi Alam. 5(4):381-388.

Mulia, F. 1995. Pertumbuhan Tegakan Dan Teknik Pengusahaan Hutan Mangrove Berkelanjutan. Buku. PT. Bina Lestari. Riau. 23 hlm.

Noor, Y.R., Khazali, M. dan Suryadiputra, IN.N. 2006. Panduan Pengenalan Mangrove di Indonesia. Buku. Wetlands International. Bogor. $220 \mathrm{hlm}$.

Okimoto, Y., Nose, A., Murdiyarso, D., Kustanti, A., Suwignyo, R.A., Sasmito, S.D. dan Tateda, Y. 2013. Study on Sustainable Development of Coastal Communities by Thinning Practices of The Rehabilitated Mangrove Trees. Tidak Dipublikasikan. Hokaido Universitty. Japan.

Onrizal. 2008. Panduan Pengenalan Dan Analisis Vegetasi Hutan Mangrove. Buku. Departemen Kehutanan Fakultas Pertanian Universitas Sumatera Utara. Sumatra Utara. $19 \mathrm{hlm}$.

Prastyono. 2014. variasi pertumbuhan pada uji provenan ulin di Bondowoso. Jurnal Wana Benih. 15(2):73-80.

Sarwono, J. 2013. 12 Jurus Ampuh SPSS untuk Riset Skripsi. Buku. Elexmedia Komputindo Kompas Gramedia Jakarta. Jakarta. 288 hlm.

Susila, I.W.W. 2010. Riap tegakan duabanga (Duabanga moluccana bl.) di Rarung. Jurnal Penelitian dan Konservasi Alam. 7(1):47-58.

Yunianti, A.D. dan Muin, M. 2009. Buku Ajar Pertumbuhan Pohon Dan Kualitas Kayu. Buku. Fakultas Kehutanan Universitas Hasanuddin. Makasar. 95 hlm. 